\title{
OPTIMIZATION OF HEAT EXCHANGER FOR INDIRECTLY HEATED WATER HEATER
}

\author{
Katarína KADUCHOVÁ, Richard LENHARD, Jozef JANDAČKA
}

\begin{abstract}
Due to the optimization of geometrical parameters of the heat exchanger in indirect heated water heaters created a mathematical model of heating hot water, by which I have subsequently made the simulation of the device to change its geometrical parameters. Based on these results, the impacts of the geometrical parameters affect the performance of the heat exchanger. The results of the optimization to create a CFD model which watched at the behavior of optimized heat exchanger for indirect heated water heaters.
\end{abstract}

\section{INTRODUCTION}

Indirectlyheatedwater heatersaredevicesused toheat up, and thenheatedfor storing drinkingwater, thesedevices providea superior usercomfort, allowinghot waterto supplya large numberof delivery points, bothin residentialas well aseconomic facilities. Theindirect heated water heater, water isheatedbythe powerspiralheat exchangersothat the water removesheat from theheatedmediumfrom an external sourceof heat.

Optimization of the heat exchanger for indirectly heated water heaters are designed to amend its geometric parameters such as tube diameter and length of the spiral tube spiral, so that we have achieved a significant increase in the heating coil performance.

\section{Mathematical model}

The mathematical model of heating hot water heating water temperature set at $80{ }^{\circ} \mathrm{C}$, cold water temperature was $15^{\circ} \mathrm{C}$, water in the boiler was heated to $60{ }^{\circ} \mathrm{C}$ and the flow of heating medium is set to $1 \mathrm{~m}^{3} \cdot \mathrm{h}^{-1}$. Mathematical model of hot water heating was created in Excel, for the temperature gradient $80 / 60^{\circ} \mathrm{C}$. (KADUCHOVÁ, K., Thesis 2010)

\section{Process transfer heat}

The process of heat transfer in indirectly heated hot water heater consists of heat transfer from hot water in the tube wall, heat conduction through the tube wall, heat transfer from the outer wall of the tube into the heated water, heat transfer from the heated water into the wall, heat conduction through the wall, and heat transfer from the outer wall into the air.

'Ing., Katarína Kaduchová, Katedra energetickej techniky, Strojníckafakulta, Žilinskáuniverzita v Žiline, Univerzitná 1, Žilina, tel.(+421) 41513 2855, e-mail: katarina.kaduchova@fstroj.uniza.sk

This is an Open Access article distributed under the terms of the Creative Commons Attribution License 2.0, which permits unrestricted use, distribution, and reproduction in any medium, provided the original work is properly cited. 


\section{HeAT TRANSFER AT FORCED CONVECTION}

To determined the coefficients of heat transfer to the inside of the spiral tube. And on the base of Reynolds number determined by the type of flow:

$$
R_{e}=\frac{w \cdot d_{1}}{v}
$$

where:

$$
\begin{array}{ll}
\mathrm{w} & - \text { mean velocity }\left[\mathrm{m} . \mathrm{s}^{-1}\right], \\
\mathrm{d}_{1} & - \text { internal diameter tube spiral }[\mathrm{m}], \\
v & \text { - kinematic viscosity }\left[\mathrm{m}^{2} \cdot \mathrm{s}^{-1}\right] .
\end{array}
$$

Nusselt number for turbulent flow determined from the relation:

$$
N_{u}=0,023 \cdot R_{e}^{0,8} \cdot P_{r}^{0,4},
$$

where:

$P_{r} \quad$ - Prandtl number [-].

The size of the coefficient of heat transfer to the inside of the spiral tube determined from the relation:

$$
N_{u}=\frac{\alpha_{1} \cdot d_{1}}{\lambda} \Rightarrow \alpha_{1}=\frac{N_{u} \cdot \lambda}{d_{1}} \quad\left[\mathrm{~W} \cdot \mathrm{m}^{-1} \cdot \mathrm{K}^{-1}\right]
$$

where:

$\lambda \quad$ - thermal conductivity $\left[\mathrm{W} \cdot \mathrm{m}^{-1} \cdot \mathrm{K}^{-1}\right]$.

\section{Heat transfer at Free CONVEction}

To determine the coefficient of heat transfer to the outside of the spiral tube, free flow is characterized by size and Grashof and Prandtl numbers, which determine the type of flow, and which is within the range $\left.\left(P_{r} . G_{r}\right)\right\rangle 2.10^{7}$ :

$$
G_{r}=\frac{\beta \cdot \Delta t \cdot g \cdot d_{2}^{3}}{v^{2}}
$$

where:

$\beta \quad-$ is the coefficient of cubic expansion $\left[\mathrm{K}^{-1}\right]$,

$\Delta t=t_{21}-t_{22}$ - temperature difference $\left[{ }^{\circ} \mathrm{C}\right]$,

$\mathrm{t}_{21} \quad-$ inlet temperature of the water $\left[{ }^{\circ} \mathrm{C}\right]$,

$\mathrm{t}_{22}$ - output temperature of the water $\left[{ }^{\circ} \mathrm{C}\right]$,

g - gravitational acceleration $\left[\mathrm{m} . \mathrm{s}^{-2}\right]$,

$\mathrm{d}_{2} \quad-$ the outside of the diameter tube spiral [m].

Nusselt number for turbulent flow determined from the relation:

$$
N_{u}=0,135 \cdot\left(P_{r} \cdot G_{r}\right)^{\frac{1}{3}}
$$

The size of the coefficient of heat transfer to the outside of the tube spiral determined from the relation: 


$$
N_{u}=\frac{\alpha_{2} \cdot d_{2}}{\lambda} \Rightarrow \alpha_{2}=\frac{N_{u} \cdot \lambda}{d_{2}} \quad\left[\mathrm{~W} \cdot \mathrm{m}^{-1} \cdot \mathrm{K}^{-1}\right]
$$

\section{Heat conduction}

Coefficient heat transfer $\mathrm{k}_{1}$ :

$$
k_{1}=\alpha_{1} \cdot S_{1}=\alpha_{1} \cdot \pi \cdot d_{1} \cdot L \quad\left[\mathrm{~W} \cdot \mathrm{m}^{-2} \cdot \mathrm{K}^{-1}\right]
$$

Coefficient heat transfer $\mathrm{k}_{2}$ :

$$
k_{2}=\alpha_{2} \cdot S_{2}=\alpha_{2} \cdot \pi \cdot d_{2} \cdot L \quad\left[\mathrm{~W} \cdot \mathrm{m}^{-2} \cdot \mathrm{K}^{-1}\right]
$$

Coefficient heat transfer $k_{3}$ through a simple cylindrical wall:

$$
k_{3}=L \cdot\left(\frac{1}{\frac{1}{2 \cdot \pi \cdot \lambda_{m}} \ln \frac{d_{2}}{d_{1}}}\right) \quad\left[\mathrm{W} \cdot \mathrm{m}^{-2} \cdot \mathrm{K}^{-1}\right] \text {, }
$$

where:

$\lambda_{m} \quad$ - thermal conductivity of copper $\left[\mathrm{W} \cdot \mathrm{m}^{-1} \cdot \mathrm{K}^{-1}\right]$.

Determination of thermal performance of the water heater:

$$
Q=\frac{t_{s t r}-t_{21}}{\frac{1}{k_{1}}+\frac{1}{k_{2}}+\frac{1}{k_{3}}}
$$

where:

$\mathrm{t}_{\mathrm{str}} \quad$ - mean water temperature in the exchanger $\left[{ }^{\circ} \mathrm{C}\right]$,

$t_{21} \quad$ - inlet temperature of water in water heater $\left[{ }^{\circ} \mathrm{C}\right]$.

\section{Heating time}

Time period of heating was determined under these conditions, when the water heater heats water from $15^{\circ} \mathrm{C}$ to $60^{\circ} \mathrm{C}$ in a volume of $100 \mathrm{I}$.

Energy requirements $\mathrm{E}$ :

$$
E=m_{v} \cdot c \cdot\left(t_{1}-t_{2}\right) \quad \text { [W.h] }
$$

Thermal power water heater Q:

$$
Q=\frac{1}{\eta} \cdot \frac{E}{\tau}
$$

Heating time $\mathrm{T}$ :

$$
\tau=\frac{E}{Q . \eta} .60
$$

where:

$m_{v} \quad$ - weight of water $[\mathrm{kg}]$,

c - heat capacity of water $\left[\mathrm{J} \cdot \mathrm{kg}^{-1} \cdot \mathrm{K}^{-1}\right]$,

$t_{1} \quad$ - inlet temperature of the water $\left[{ }^{\circ} \mathrm{C}\right]$, 


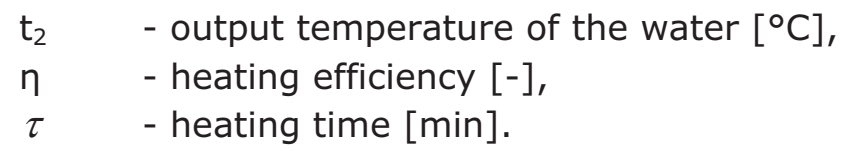

\section{Mathematical simulations}

In mathematical simulations of indirectly heated hot water heater was investigated by the impact of changes in geometric parameters of the heating element - diameter (d) and length tube spiral (L). Simulations program of hot water heating was created in Excel.

For the model type was used indirectly heated water heater (Figure 1.) with the following geometrical parameters:

$\mathrm{H} \quad$ - the amount of heater water0.955 m,

D - the width of the water heater0.520 m,

$\mathrm{V} \quad$ - the volume of water heater100 I,

L $\quad$ - length tube spiral9.880 m,

$\mathrm{d}_{1} \quad$ - internal diameter tube spiral0.028 m,

$\mathrm{d}_{2}$ - external diameter tube spiral0.032 m,

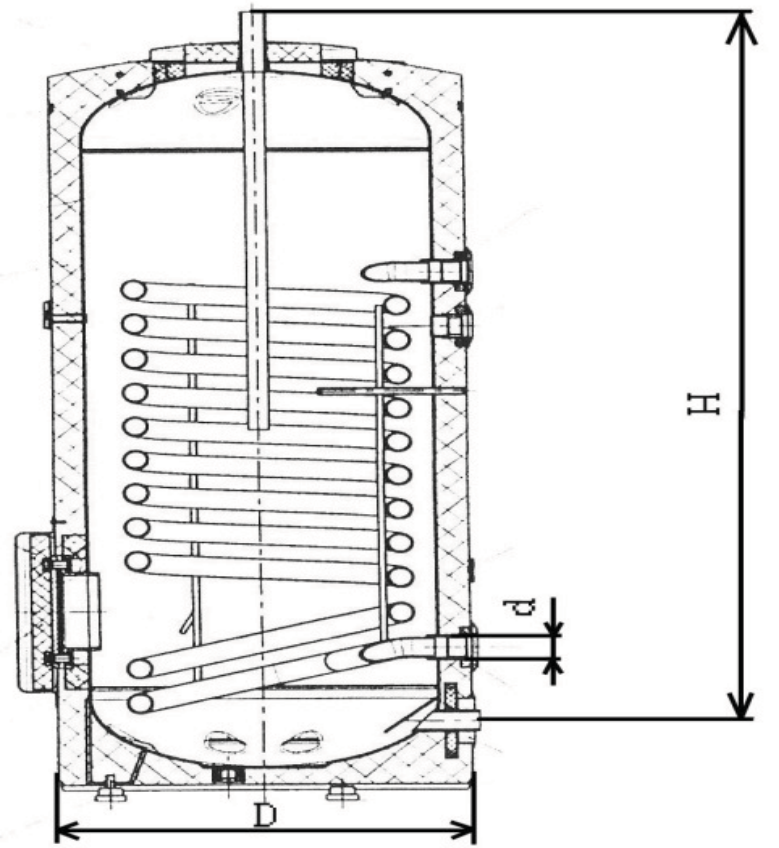

Figure 1: Indirectly heated water heater

\section{RESULTS OF MATHEMATICAL SIMULATIONS WHEN CHANGE DIAMETER OF TUBE SPIRAL}

In mathematical simulations for the constant geometric parameters - height of the water heater, width water heater, the volume of the water heater, length tube spiral, where varied only diameter tube spiral from the original $0.018 \mathrm{~m}$ to $0.057 \mathrm{~m}$. For the mathematical simulations were used normalized averages of copper tubing. Change in diameter tube spiral to monitor the change in the performance heating spiralQand heating time $\tau$. Results of mathematical simulations are presented in table 1. 
Table 1: Results of mathematical simulations when change diameter of the tube spiral d

\begin{tabular}{|l|r|r|r|r|r|r|r|}
\hline $\mathbf{d}_{\mathbf{2}}$ [m] & $\mathbf{0 , 0 1 8}$ & $\mathbf{0 , 0 2 0}$ & $\mathbf{0 , 0 2 2}$ & $\mathbf{0 , 0 2 5}$ & $\mathbf{0 , 0 2 8}$ & $\mathbf{0 , 0 3 0}$ & $\mathbf{0 , 0 3 2}$ \\
\hline $\mathbf{Q}$ [W] & 7313,8 & 7775,5 & 8172,1 & 8739,9 & 9115,3 & 9309,6 & 9560,4 \\
\hline$\tau$ [min] & 43,859 & 41,255 & 39,253 & 36,702 & 35,191 & 34,457 & 33,552 \\
\hline & & & & & & & \\
\hline $\mathbf{d}_{\mathbf{2}}$ [m] & $\mathbf{0 , 0 3 5}$ & $\mathbf{0 , 0 3 8}$ & $\mathbf{0 , 0 4 2}$ & $\mathbf{0 , 0 4 4 5}$ & $\mathbf{0 , 0 5 4}$ & $\mathbf{0 , 0 5 7}$ & \\
\hline $\mathbf{Q}$ [W] & 9635,9 & 9743,9 & 9810,3 & 9816 & 9756,1 & 9669,1 & \\
\hline$\tau$ [min] & 33,29 & 32,921 & 32,698 & 32,679 & 32,879 & 33,175 & \\
\hline
\end{tabular}

When changing the diameter of the tube spiral of $0.018 \mathrm{~m}$ to $0.057 \mathrm{~m}$, it when diameter tube spiral $0.0445 \mathrm{~m}$ to reach the highest heat output to 9816 watts, and heating time is $32.68 \mathrm{~min}$.

\section{RESULTS OF MATHEMATICAL SIMULATIONS WHEN CHANGE THE LENGTH OF TUBE SPIRAL}

In mathematical simulations for the constant geometric parameters - height of the water heater, width water heater, the volume of the water heater, diameter tube spiral, which varied only the length of the tube spiral tube of $4 \mathrm{~m}$ to $20 \mathrm{~m}$. While the change followed the change in the performance heating spiral $Q$ and the heating time $\tau$. Results of mathematical simulations are listed in table 2 .

Table 2: Results of mathematical simulations to change the length of the tube spiral L

\begin{tabular}{|l|r|r|r|r|r|r|r|r|r|}
\hline $\mathbf{L}[\mathbf{m}]$ & $\mathbf{4}$ & $\mathbf{5}$ & $\mathbf{6}$ & $\mathbf{7}$ & $\mathbf{8}$ & $\mathbf{9}$ & $\mathbf{1 0}$ & $\mathbf{1 1}$ & $\mathbf{1 2}$ \\
\hline $\mathbf{Q}[\mathbf{W}]$ & 3870,6 & 4838,3 & 5805,9 & 6773,6 & 7741,2 & 8708,9 & 9676,5 & 10644 & 11612 \\
\hline$\tau$ [min] & 82,875 & 66,3 & 55,25 & 47,357 & 41,437 & 36,833 & 33,15 & 30,136 & 27,625 \\
\hline & & & & & & & & & \\
\hline $\mathbf{L}[\mathbf{m}]$ & $\mathbf{1 3}$ & $\mathbf{1 4}$ & $\mathbf{1 5}$ & $\mathbf{1 6}$ & $\mathbf{1 7}$ & $\mathbf{1 8}$ & $\mathbf{1 9}$ & $\mathbf{2 0}$ & \\
\hline $\mathbf{Q}[\mathbf{W}]$ & 12580 & 13547 & 14515 & 15482 & 16450 & 17418 & 18385 & 19353 & \\
\hline$\tau$ [min] & 25,5 & 23,678 & 22,1 & 20,719 & 19,5 & 18,417 & 17,447 & 16,575 & \\
\hline
\end{tabular}

The results obtained suggest that the change in the length of the tubes spiral of $4 \mathrm{~m}$ to $20 \mathrm{~m}$, will increase the heat output of 15.482 watts, and also reduce heating time of $82.88 \mathrm{~min}$. to $16.58 \mathrm{~min}$., for the length of the tube spiral $20 \mathrm{~m}$. When changing the length tube spiral of $4 \mathrm{~m}$ to $20 \mathrm{~m}$, will increase performance and reduce heating time.

\section{OPTIMIZATION GEOMETRICAL PARAMETERS OF HEAT EXCHANGER}

Optimization of the heat exchanger for indirectly heated hot water heater has been designed to change the geometric parameters and the length of the spiral tube of 4 $\mathrm{m}$ to $20 \mathrm{~m}$, and change the tube diameter coil of $18 \mathrm{~mm}$ to $57 \mathrm{~mm}$. 


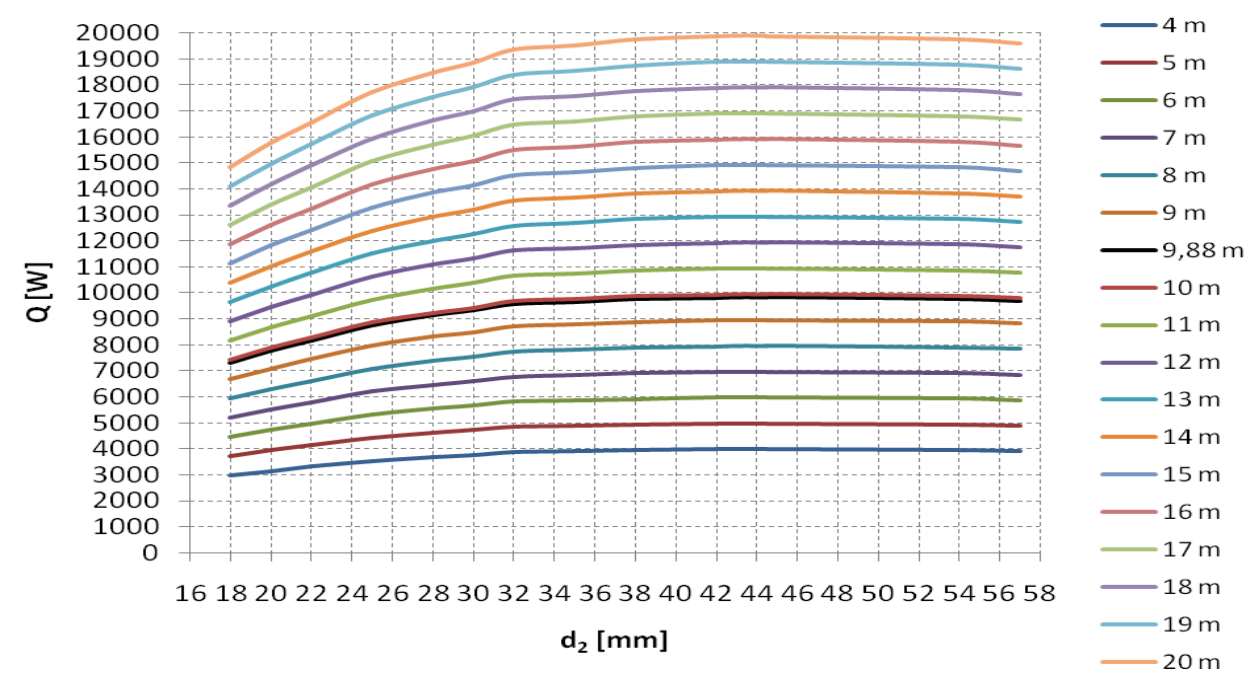

Figure 2: Dependence ofheat outputfrom the heat exchanger from spiraltubesindifferent lengths

Depending on the performance of the heat exchanger from the average spiral tube (Fig.2) shows that the greatest power in the spiral tube diameter is spiral tube $0.0445 \mathrm{~m}$, and any change in the length of the spiral tubes from $4 \mathrm{~m}$ to $20 \mathrm{~m}$. For any tube diameter from $0.018 \mathrm{~m}$ spiral to $0.057 \mathrm{~m}$ was found that with increasing tube spiral from $4 \mathrm{~m}$ to $20 \mathrm{~m}$, the spiral tube performance increases, but only to a certain average and exceeded the average performance of the spiral tube begins to decline. If maintaining the original length of the spiral tube $9.88 \mathrm{~m}$ and by changing only the diameter of the spiral tube of the original $0.032 \mathrm{~m}$ to the value at which to achieve maximum performance spiral tube, and the spiral tube diameter $0.0445 \mathrm{~m}$, and thethis average, we achieved $9.82 \mathrm{~kW}$ heating power. While maintaining the spiral tube diameter $0.032 \mathrm{~m}$, and only changed the length of the spiral tube of the original $9.88 \mathrm{~m}$ at any greater length, there would always be to increase the performance of the heating spiral. Therefore, the optimization is necessary to take into account both the geometrical parameters, length and diameter spiral tube to achieve a substantial increase in the heating spiral performance.

\section{Proposalparametersof the heat exchangerforindirectlyheatedwater heater}

They suggestthat thesegeometric parameters ofthe heatingcoils:

L $\quad$ - length tube spiral20 m,

$\mathrm{d}_{1} \quad$ - internal diameter tube spiral0.0415 m,

$\mathrm{d}_{2} \quad$ - external diameter tube spiral0.0445 m,

Q - heat output $19.89 \mathrm{~kW}$.

\section{NUMERICAL SIMULATION OF INDIRECTLY HEATED HOT WATER HEATER}

Numerical models are developed on the basis of real model. It was created 9 models which were selected from mathematical simulation. Results of selected mathematical simulation are shown in Table 3 and the dependence of heating time from a length and pipe of diameter. 


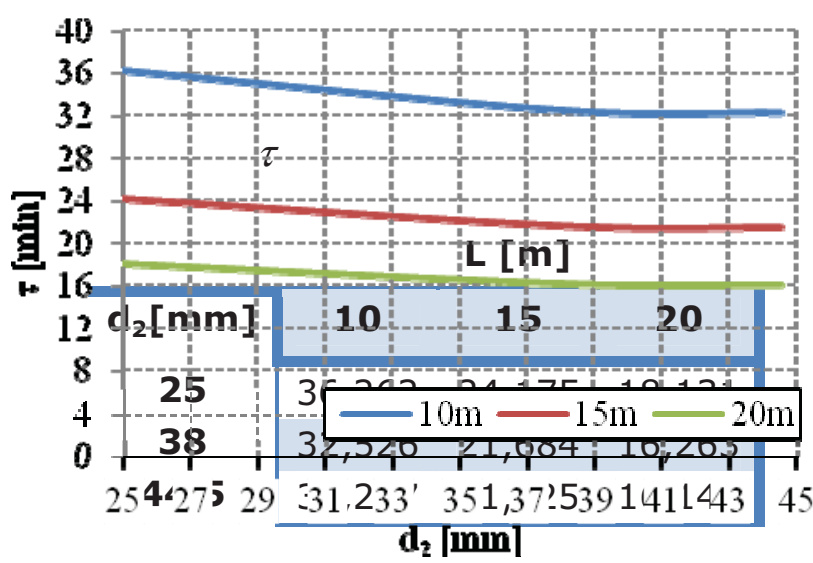

Table 3: Results heating time ( $\mathrm{min}$ ) of selected models fr om mathematical simulations

Geometry model was created in the program Gambit under proposed a construction. In a Gambit was created automatic mesh (Fig. 3) and was sets boundary conditions (water temperature at the inlet, velocity media, media type and its physical properties).

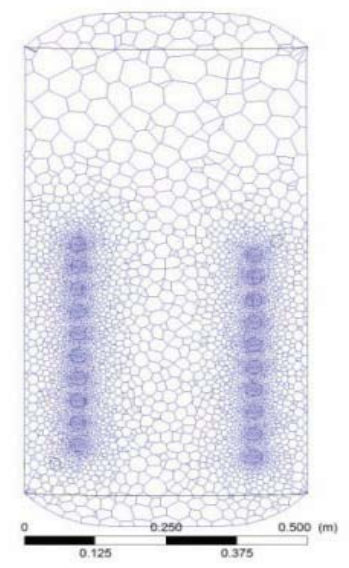

Figure 3: View of the polyhedral mesh

Thus formed was transferred to a model simulation program Fluent where was mesh transform to the polyhedral mesh.

Fluent is common CFD software which defines boundary conditions, which area precondition for the correct calculation. (Lenhard, Jandačka 2008)

Turbulentmodel was sets as SST k- $\omega$ turbulence model is a two-equation eddy-viscosity model which has become very popular. The shear stress transport (SST) formulation combines the better of two worlds. The use of a $k-\omega$ formulation in the inner parts of the boundary layer makes the model directly usable all the way down to the wall through the viscous sub-layer; hence the SST k- $\omega$ model can be used as a Low-Re turbulence model without any extra damping functions. The SST formulation also switches to a $k-\varepsilon$ behavior in the free-stream and thereby avoids the common $\mathrm{k}-\omega$ problem that the model is too sensitive to the inlet free-stream turbulence properties. Authors who use the SST $k-\omega$ model often merit it for its good behavior in adverse pressure gradients and separating flow. The SST $k-\omega$ model does produce a bit too large turbulence levels in regions with large normal strain, like stagnation regions and regions with strong acceleration. This tendency is much less pronounced than with a normal $k-\varepsilon$ model though (www.cfd-online.com). 


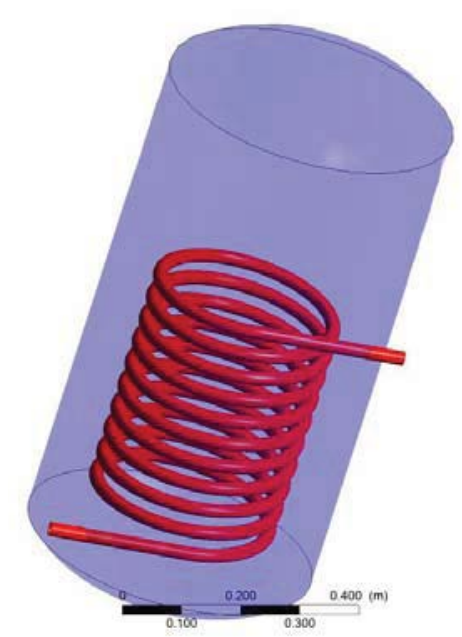

Figure 4: Geometry model indirectly heated water heater for numerical simulation (10 $\mathbf{~ m}$ length exchanger and a diameter pipe of $\mathbf{2 5} \mathbf{~ m m}$ )

\section{Simulations were conducted for the following input conditions:}

- Turbulent model: SST k - $\omega$.

- Input: velocity - inlet.

- Output: pressure - outlet.

- Water in boiler and tube: fluid.

- Cuprum tube: thickness wall and shell conduction.

- Gravitational acceleration $9.81 \mathrm{~m} \cdot \mathrm{s}^{-1}$.

- Solver: transient (time step size $60 \mathrm{~s}-40$ number of time steps).

Results of numerical simulation are shown in Table 4 and the dependence of heating time from a length and pipe of diameter.

Table 4 Results heatin $\mathrm{g}$ time $\tau(\mathrm{min})$ of sel ected models from numerical simulations

\begin{tabular}{c|ccc|} 
& \multicolumn{3}{c}{$L[\mathbf{m}]$} \\
\hline $\mathbf{d}_{\mathbf{2}}[\mathbf{m m}]$ & $\mathbf{1 0}$ & $\mathbf{1 5}$ & $\mathbf{2 0}$ \\
$\mathbf{2 5}$ & 40 & 33 & 29 \\
$\mathbf{3 8}$ & 20 & 18 & 16 \\
$\mathbf{4 4 , 5}$ & 17 & 15 & 13 \\
\cline { 2 - 3 }
\end{tabular}

As an example (Fig. 5), sample where the best result water heaters was achieved the shortest heating time of the in CFD model which is in conformity with an approximate mathematical model. It is indirectly heated water heater with exchanger length of $20 \mathrm{~m}$ and a diameter pipe of $44.5 \mathrm{~mm}$. 


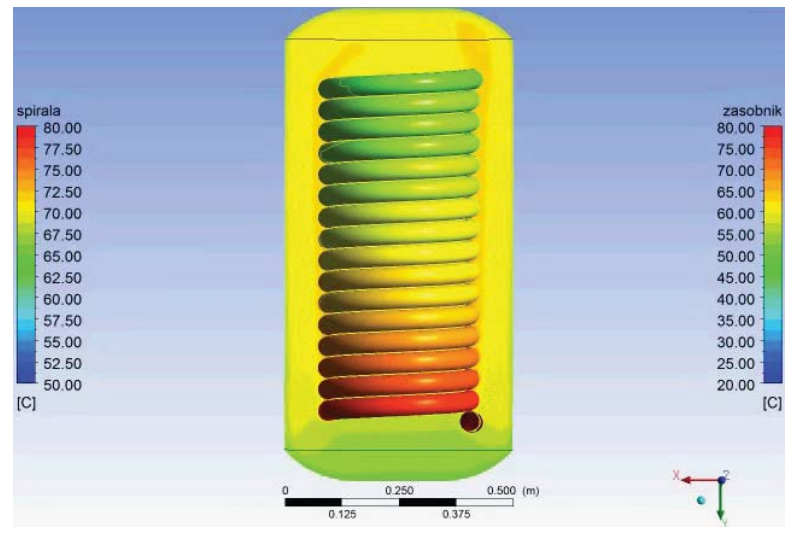

Figure 5: Results of numerical simulations with 20 m length spiral and a diameter tube of $\mathbf{4 4 . 5} \mathbf{~ m m}$

Figure 6 is a preview of the result obtained in the CFD models with the original geometric parameters (10 m length exchanger and a diameter pipe of $25 \mathrm{~mm}$ ). The CFD model was reached, heating time $40 \mathrm{~min}$.

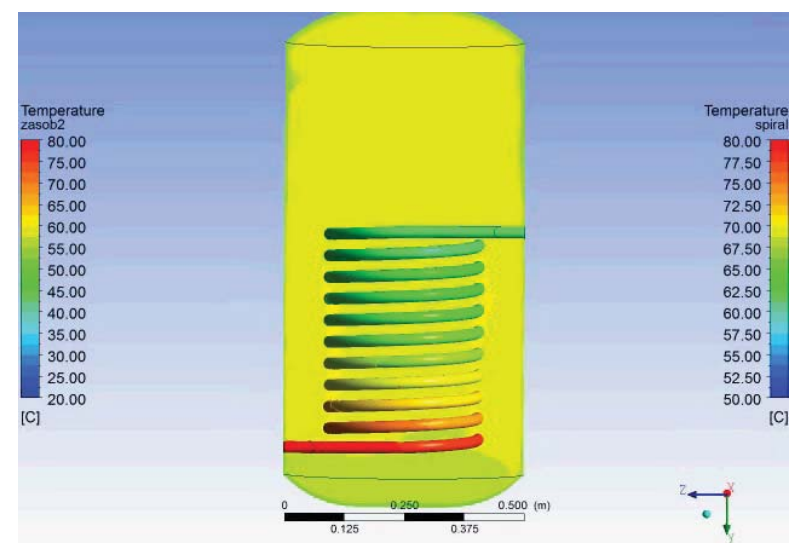

Figure 6: Cut of model indirectly heated water heater showed velocity and temperature in the heater (10 $\mathbf{~}$ length exchanger and a diameter tube of $\mathbf{2 5}$ mm)

\section{CONCLUSION}

The results obtained from mathematical simulations of indirectly heated hot water heater, the temperature gradient $80 / 60{ }^{\circ} \mathrm{C}$, it was found that the geometric parameters affecting the thermal performance indirectly heated hot water heater. The simulations showed that the increase of thermal power water heater affects mainly spiral tube length and diameter spiral tube to a diameter of $0.0445 \mathrm{~m}$ beyond the average output of the water heater begins to decline. The results of the mathematical simulation we get the maximum value of storage water heaters, where the geometric parameters of the proposed heating element ( $L$ - length of the spiral tube $20 \mathrm{~m}, \mathrm{~d}_{1}$ - inner diameter tube spiral $0.0415 \mathrm{~m}, \mathrm{~d}_{2}$ - outer diameter spiral tube $0.0445 \mathrm{~m}$ ), which achieved an increase in heating power of $10.97 \mathrm{~kW}$ to $19.89 \mathrm{~kW}$ on theoretical. To confirm the correctness of the mathematical model of indirectly heated hot water heater is necessary to verify the measurement. 
CFD simulation results will be verified on real models, if the results are consistent with the CFD model, we use a CFD model for further simulations.

\section{ACKNOWLEDGEMENTS}

Article was prepared under the number 1/1127/11 "Transport tepla prirodzenou konvekciou z orientovaných teplovýmenných plôch".

\section{REFERENCES}

[1] Kaduchová K.: Výpočet funkčných vlastností nepriamo vyhrievaných zásobníkových ohrievačov, Thesis 2010, Katedra energetickej techniky, Žilinská univerzita v Žiline.

[2] Čarnogurská M.: Základy matematického a fyzikálneho modelovania $v$ mechanike tekutín a termodynamike, Košice, Vienala, 2000, ISBN 80 - 7099 $344-8$.

[3] Lenhard R., Jandačka J.:Numerické modelovanie pasívneho stropného chladiaceho konvektora. Colloquium Fluid Dynamics Institute of Thermomechanics AS CR, v.v.i., Prague : 2008, ISBN 978-80-87012-14-7.

[4] Papučík Š., Pilát P., Kapjor A., Smatanová H., Horváth Z.: Flow field optimalization in the tunnel with oblong fan system from the aspect of energetic severity and fire safety. TRANSCOM 2007, Žilina. ISBN 978-80-8070-696-8.

[5] Sýkora D., Strážovec I., Benčíková J.: Vplyv geometrie teplozmenných plôch na prenos tepelnej energie systému para-voda. Trendy $v$ technike prostredia, Zborník prednášok odbornej konferencie 4.- 5.5.1997, Nové mesto nad Váhom, s.21-26.

[6] Huzvar J., Nosek R.: Impact of fuel supply to concenration of emissions in domestic boiler, Fourth Global Conference on Power Control and Optimalization, rocnik 4, rok 2010, cislo 1, ISBN 978/983-44483-32.

[7] Fluent Inc. of Ansys Inc. Gambit 2.2, Documentation. User's Guide, 2006.

[8] Fluent Inc. of Ansys Inc. Fluent 6.3, Documentation. User's Guide, 2006.

[9] www.cfd-online.com 